\title{
Students’ Academic Self-Concept: A Founding Strategy in Learning Process
}

\author{
Jusuf Blegur $^{1 *}$, M. Rambu P. Wasak ${ }^{2}$, Poho Pabala ${ }^{3}$
}

\begin{abstract}
Educators expect that the students perform optimally in order to support the achievement of learning objectives. However, they need to reflect the internal and external environments created to support the direction of the totality of students or vice versa. This study reports a qualitative investigation concerning to strategies that train the development of students' academic self-concepts during the learning process. There were four sixth semester students of Physical Education, Health, and Recreation program who are willing to be actively involved in sharing their learning experiences, including: 1) Lodolaleng D, 2) Lassa YY, 3) Nalle FJB, and 4) Nama LR ( $\mathrm{M}=21.5$ years). Researchers used participation observation techniques, in-depth interviews, field notes, and focus group discussions when collecting data. The results proved the students' academic self-concept is trained using six strategies, including: 1) Logical consequences, 2) Challenging responsibilities, 3) Dynamic expression media, 4) Solution-based feedback, 5) Direct evaluation of learning outcomes, objective, and transparent, and 6) Integrating thoughts and behaviors that motivate.
\end{abstract}

\section{Keywords: Academic Self-Concept, Learning Strategy}

When educators and students set foot first time in classroom, they never ignore the momentum of introduction. Introduction is not only about the identity of educators, but is more meaningful meaning that to agree on a series of rules that become references during learning process, such as the mechanism of test, assessment, and evaluation of learning outcomes. Sometimes there are some educators perceiving the process of introduction is just the routines so that they always ignore the introductory activity. In fact, it is the starting point of educators to triger the students' confidence and efforts to learn in order to maximally complete the learning. The offer of a series of test models, assessments, and evaluations by educators reflects that educators unfold the "strategies" for students' learning outcomes. In this sense, if the students want to pocket a good grade, then they will guestion their academic capacity and how the academic capacity is manifested in concrete and measurable learning efforts.

\footnotetext{
${ }^{1}$ (Faculty of Teacher Training and Education, Artha Wacana Christian University, Indonesia)

2 (Faculty of Teacher Training and Education, Artha Wacana Christian University, Indonesia)

${ }^{3}$ (Faculty of Teacher Training and Education, Artha Wacana Christian University, Indonesia)

*Responding Author
}

Received: May 22, 2018; Revision Received: October 25, 2018; Accepted: November 20, 2018

(C) 2018 Blegur. J, Wasak. M. R. P, \& Pabala. P; licensee IJIP. This is an Open Access Research distributed under the terms of the Creative Commons Attribution License (www.creativecommons.org/licenses/by/2.0), which permits unrestricted use, distribution, and reproduction in any Medium, provided the original work is properly cited. 
Academic beliefs and academic efforts are two important compositions in the attribute of students' academic self-concept (Liu \& Wang, 2005). Practically, the concept of selfacademic is defined as the introduction of the individual on his own academic quality. Similar views are also presented by Ordaz-Villegas, Acle-Tomasini, \& Reyes-Lagunes (2014) that the academic self-concept is the students' perception of their own academic ability. The self-concept of academic is mentioned as an important factor in the attainment of education (Rossen, 2010), because academic self-concept is as one of constructs that holistically describes the academic attributes of learners (Kaur \& Kumaran, 2016) and increases in line with age, as it exhibits developmental trends (Chen, Yeh, Hwang, \& Lin, 2013). Shaping well academic activities during the learning should begin with the intrinsic encouragement of learners to perceive the academic quality they have. The existence of learning efforts that the students do is because they know their own academic quality and their own learning achievement.

The construction of academic self-concept on descriptive aspects is exemplified by: "I love micro teaching lessons or I can learn easily". While evaluative aspects such as: "I am maximal in physical education or I'm good on all subjects”. The two examples above also reaffirm the argumentation by Strein's (1993). He argues that academic self-concepts tend to focus on scholastic competence (logic systems), not on attitudes. Students should complete the tasks and responsibilities to learn because of a good logic system (Tlonaen \& Blegur, 2017). Examination conducted by Noriasih (2013) proves that students with high academic self-concept is more superior in the reciprocal and conventional teaching models of learners than the students with low academic self-concept. This means that external experiments do not guarantee a prominent change in students' learning behavior without the support of a mature academic self-concept composite. That is why academic self-concept is an important element in the development of learning quality.

Various academic literatures have explained the evidence of the efficacy of self-concept in encouraging the achievement of academic performance and learning outcomes of students (Marsh, 1987; Byrne, 1996; Marsh \& Martin, 2011; Matovu, 2012; Yusuf, Dramanu, \& Balarabe, 2013). Efficacy is not only linearity and it is even causal, self-concept not only influences achievement but a good academic achievement makes learners have ethical responsibility to always believe and strive to improve the existing achievement (Muijs, 1997; Pinxten, de Fraine, van Damme, \& D’Haenens, 2010; Chen, Yeh, Hwang, \& Lin, 2013) so that educators should give a good portion to train students' academic self-concept (Tlonaen \& Blegur, 2017). Students' general performance in learning process can be predicted with academic self-concept (Ghazvini, 2011), including improving learning motivation (Marsh, Trautwein, Ludtke, Koller, \& Baumert, 2005), testing students' learning anxiety (Kaur \& Kumaran, 2016), as well as controlling students' anxiety in communicating (Blegur, Mae, \& Wasak, 2018).

Discussion method and personal presentation have assisted educators observe the various of student learning phenomena including their academic self-concept. Some students perform a high level of academic confidence and a resilient academic endeavor with varying perceptions and learning behaviors. They are active, participatory, and energetic in learning class characterized by quality presentations that is measurable. The formation of the academic self-concept does occur with various interventions, both coming from inside (students' learning experience) and from the outside (the learning design that the educator develops). Observing many positive benefits of academic self-concept that affirm the quality of students' learning outcomes, this study aims to conduct qualitative exploration as an effort 
to determine the strategies that contribute in the formation of students' academic self-concept throughout their educational learning experience.

\section{METHODOLOGY}

This research used qualitative approach with explorative design. Researcher only described the exploration results of research problem in the form of words to find the variables that affirm to train participants' academic self-concept during the learning process. Participants were six semester students of Physical Education, Health, and Recreation Program, Artha Wacana Christian University, Kupang, consisting of four people; 1) Lodolaleng D, 20 years, 2) Lassa YY, 24 years, 3) Nalle FJB, 21 years, and 4) Nama LR, 21 years old. Qualitative data prepared in a series of analytical support processes were collected using participant observation techniques, in-depth interviews, field notes, and focus group discussions (FGDs).

Participatory observations focused on participant phenomena in behaviors relating to beliefs and academic efforts. In-depth interviews tracked the areas of views, opinions, and how and why the participants' academic self-concept was high. Field notes played role to confirm oral data or interviews submitted by participants either from social media or evaluation of learning while FGD addressed the aspects of understanding and logical argument that underlie the variables that trained participants' academic self concept. The analytical process was adopted from John W. Creswell model in 2009 to reveal the affirmative meaning of participants’ self-conceptual concepts as positive and constructive learning behaviors.

\section{RESULTS AND DISCUSSION}

\section{Logical Consequences}

Students needed to be awakened from the beginning so that they knew what learning behavior is needed and considered during the learning process per semester forward. Learning has a purpose, and this goal must be achieved to require a number of strategies to ensure learning activities undertaken by students are able to answer the learning objectives. Agreeing the rules and consequences is very important in order to cultivate the critical ability to students in considering their learning culture. For instance, what happens if they are late to attend the class, to submit tasks, do not know to download the journal, lack of mastering the presentation material, and so forth. Actually this consequence is not based on punishment, but the preventive efforts that educators do based on rationality in order to avoid students do destructive behavior. For instance, student which is less in mastering the presentation material because of the minimum time for studying is given the opportunity to represent the material while overcoming the timetable setting board so that he is more organized in using learning time and socializing.

How can these logical consequences be useful in training students' academic beliefs and efforts? Before learning is executed, educators and students discuss and agree on appropriate and inappropriate learning behaviors. Besides, according to Almasitoh (2012) that to give the students choice and or responsibility for positive actions and negative actions and the consequences. Logical consequence teaches learners to understand the reasons for setting up or disciplining them to internalize and follow without coercion or fear as well as acknowledge and reward good efforts and behavior (Center for Justice and Crime Prevention, 2012). Logical consequences also awaken the student to good faith and endeavor as they begin to be respected in many ways, as Nalle (male, 21 years old) expressed: "as the highest reward for a hard worker is not what he obtains, but what the hard work makes him". Appreciating hard work and efforts is non-narcissistic that has short adventages, yet teaching 
students to contribute to learning progress and addressing challenges elegantly although there are some improvements.

The application of these logical consequences is effective for the students' beliefs and academic efforts by taking into account four key indicators, such as: interrelated, respecting the right of students, logically acceptable, and dialogical (Simanjuntak, et al., 2017). Students will be comfortable with the attitude of empoweing, appreciating and being rational as well as rich solution done by the educators. They naturally approached educators to discuss obstacles faced with relaxed and comfortable. At the same time educators have fostered the self-worth of students, moreover the solutions offered to solve learning problems was acceptable and proven successfully. They were then convinced that they learn with the right and proper guidance so that they continue to be motivated to make voluntary, energetic, and continuous learning changes. Thus, a good logic system has ensured a problem-based discussion process (Glaser, 1984) and improved academic self-concept (Strein, 1993) while maintaining the dignity of students as glorious social beings.

\section{Challenging Responsibility}

Subjects that educators think challenges are writing papers on the spot (during classroom learning) and reporting the results with a personal presentation. The student was given five weeks to composite a paper with minimum number of words more or less 1,000 (introduction, discussion, and conclusion) in which they were accompanied by educator. The preparation of papers was got around by giving journal and print process, such as Scholaria: Jurnal Pendidikan dan Kebudayaan, Satya Widya, Jurnal Kesehatan Jasmani dan Olahraga, Proceeding of Seminar on Educational Research and so on. Educators also assign students to search for electronic versions of journals such as Google Scholar and/or Directory of Open Access Journals that were related to the topics they write. This responsibility challenged students because it required a strong self-sincerity because it is a way of learning that is still "lay" for them. Especially when working on papers in place and presenting independently indeed the terms of belief and academic effort finally is inevitable as part of the way students express the quality of learning.

Each student had an academic capacity that was different from others, but as a prospective educator, writing papers and doing presentations are not a new thing for students later. Trying new things is very interesting for students who yearn for change, as Lassa (female, 24-yearold) says: "When I work on paper on the spot I have a little trouble, like writing paragraph, quoting, and writing references. But I'm sure I can do it with the team by trying to read more." Furthermore, Nama (male, 21 years old) added: "We are not used to do such learning (writing paper on the spot and presenting it), but in this way my ability is continually trained to try to prepare self better."Challenging responsibility can create a learning environment in which students can develop their maximum potential for every form of work required for their class (Saxon, 2013) which can also make learning activities effective (Almasitoh, 2012) and improve students' motivation in learning (Blegur, 2017).

When participants do not get or are given challenging responsibilities, they assume that educational institutions are not a place for learning because they are not accustomed to control their abilities through their work (Bacon, 1993), thus providing challenging responsibility is not to test students' abilities, but to test the efforts to develop capabilities. Although challenging, students actually enjoy individual presentation when successfully delivering the material (Blegur, 2017). Moreover, they also feel that they are getting new things, even in challenging conditions they will remain confident and try as long as they get 
an intense and clear guidance and assistance from educators. Students may be given challenging responsibility if the educator is also responsible for facilitating the academic success and achievement of students (Saxon, 2013) by reviving the classroom, creating explicit expectations, forming smaller study groups, considering attendance consequences, consistency of assessment, removal of additional credits model, and reorganization of liability responsibilities (Hassel \& Lourey, 2010).

\section{Dynamic Expression Media}

When working on a paper, students are free to ask questions and discuss with other groups without restrictions so that the "pacing" activity in the class should be allowed in order to extract information about the material, rather than being silent and polite but not critical and creative (Blegur, Wasak, \& Manu, 2017). The most important is the tone of their "free" feelings that trigger high curiosity. Lodolaleng (male, 20 years old) explained his experience: "I am increasingly convinced of the academic ability in the learning environment that gives me the opportunity to express opinions and give inputs or discussions". Responsibility that is given to the students is non-monotonous in common areas such as full lectures, yet responsibility also gives opportunities for students to express their self in the ways that they consider as powerful asset in themselves, such as personal presentations and group discussions. A full lecture is actually a form of deprivation on students' creativity and critical ability. Students' poor critical thinking is caused by the lack of the opportunity to express, and poor creativity is caused by unopened attitude to inputs and new things during the learning activities.

The academic self-concept is formed and developed through interaction with others, i.e. educators and peers, and/or parents (Rossen, 2010). The intensity of interaction enables students to think and act more actively to make use the time in learning that can be mediated by personal presentations. Moreover, the personal presentation set the students to not to escape from the activities of "ideas and skills competitions", they get the opportunity to report their own work and their learning experiences or material they share to others are ready to be refuted (Blegur, 2017). A presentation is an art of influencing people, so let the students in their own way influence each other by using their ideas and skills. As long as they feel the way they do makes them easier to influence others. We achieve learning outcomes by appreciating the unique learning of each student (Juliani \& Meliana, 2014). Therefore learning activities are actually not solely implemented because of the educator authority, but the result of consensus between educators and students to learn in dynamic and relaxed situations but has meaningful values.

Learning is students' activity to exert all of their potential (Gulo, 2002). The positive classroom environment is a valuable part of education and encourages the mood and satisfaction of students (Trickett \& Moos, 1974) so that a positive and interesting learning design is the most important part as the effort to encourage students' self-potential. Educators should not assume that the relaxed learning design makes the students indifferent and passive. Classroom learning can be designed by educators with a relaxed mood, but it does not mean to pamper students in their learning efforts (Blegur, 2017). The development of tasks and learning behaviors become the focus by the educator during learning activities. It affirms that relaxation is not localized to the learning effort, but to the mood or feelings of students while learning. By learning on a stable and positive mood, students can develop their academic and self-concept (Efklides \& Petkaki, 2005) which is characterized by the confidence and academic efforts that they have done to develop themselves maximally, as the goal of national education in Indonesia. 


\section{Solution-Based Feedback}

Educators would be proud and happy when the students complete their learning with satisfactory results. However, the process of achievement is not as easy as what we dream, there are various obstacles that sometimes occur outside the control of educators and even the constraints created by educators themselves. There are students who are so easy and quick to understand instructions and materials, and some are slow and limited that are often known as the constraints or learning difficulties. Each learning activity must encounter obstacles, yet we do not avoid the constraints but find the solution or reduce the problems so that learners can understand and develop the subject matter easily. Educators can use feedback that is not based only on judgment, but also a useful feedback for students which offer a solution to student work. If educators just scribble on students' works (paper or presentation) without a solution, then a primary school kids can do the same, scribbling is easy, isn't it?

When getting feedback, students really miss meaningful and useful views. Inputs should bridge students to their openness to recognize constraints that need to be fixed. As Lodolaleng (male, 20 years old) argued "Feedback appreciation is as a stimulus to increase confidence and solutive feedback improve myself. Thus, I try not to repeat it, keep learning, and are not satified too fast to what I have". The solution-based reward will stimulate the beliefs and efforts of students in completing their learning tasks (Blegur, 2017), as well as legitimize the personal and academic quality of students. Solution feedback is more acceptable and provides warranty for the follow up of improved performance. In addition, the findings by Snyder \& Cowles (1979) underscored that personality feedback has a higher impact on intellectual feedback. Thus, when applying feedback, educators need to encourage students' personality to learn, for example: "Your results are good, by studying hard, you will perform the presentation maximally".

The effectiveness of feedback needs to notice the delivery mode and the timeliness when the student is listening to the inputs. It is done in order to make good personal relationships between educators and students as well as fellow students, the solutive feedbacks need to notice gender differences (Matovu, 2012), and students who receive positive feedback tend to feel satisfied with the results of their own work (Burnett, 2010). Solutive feedbacks give reflective practice in order to affirm the establishment of a conceptual framework, improvement of instructional practices, professional development, and the development of collegiality (Bell, 2010). Solutive feedbacks not only improve the quality of learning, but also facilitate the transition between school period and college period (Poulos \& Mahony, 2008), by encouraging confidence and the academic efforts, cognitive function can improve quality of learning (Ordaz-Villegas, Acle-Tomasini, \& Reyes-Lagunes, 2014). With humanity and solutive treatment, students are more sensitive in accepting solutions and improving their academic performance and quality with the confidence and academic effort they have.

\section{Direct, Objective, and Transparent Evaluation of Learning Outcomes}

Evaluation is a media to update students' learning outcomes rather than to judge. On this basis, educators undertake a range of strategies to diagnose students' learning performance, which includes the presentation observation guidance. Presenters are diagnosed on ten dimensions, either in terms of self-appearance to management or classroom management. The results of the diagnosis are then discussed together (presenter and observer) then returned to the students (presenter) as a follow-up reference. As Nalle (male, 21-year-old) felt, that: "When educators engage directly in evaluations and discussions, it gives reinforcement and confidence in me to continue learning". Direct evaluation is necessary because the students want to know the results they have obtained, and in such conditions, they are very motivated 
to improve themselves. Then objectivity supports the direction of their motivation, which they feel realistic with the results of their performance. While transparency encourages a positive tendency on educator professionalism to evaluate in order to maintain and increase the totality of student participation.

Perception and academic effort are as the medium for students to conduct self-evaluation (Tlonaen \& Blegur, 2017). Students want to know their academic performance as the evidence of academic quality. Direct, objective, and transparent evaluation builds students' realistic attitudes as well as humanistic educational techniques. Students are satisfied with the professionalism of educator, because evaluation is performed openly and without discrimination. It means that students hold the same presentation guidelines, so that if the evaluation process tends to nepotism, then it will stimulate the dissatisfaction of academic services. Sometimes students are apathetic. It is not because they have learning difficulties, but they are disappointed with the evaluation process which tends to nepotism ended with poor academic concepts. They think that the abilities they believed and the efforts they do are futile because of indirect, subjective, and exclusive evaluation activities. The reflective statement was commonly used by students is: "School work is easy for me or I always do better than the others” (Bong \& Skaalvik, 2003).

Positive self-concept (belief and effort) is an important mediator for other outcomes (Marsh \& Martin, 2011) that can be trained with continuous evaluation activity (Blegur, Wasak, \& Manu, 2017). Evaluation proved to have an impact on students' emotions, moods, and learning behaviors (Much \& Klauer, 2003). A direct, objective, and transparent evaluation process provides an evaluative meaning deeply in students' self-belief and their affective nature to continue to improve through learning efforts (Clore \& Colcomber, 2003). This is the starting point in which evaluations contribute to training students' academic beliefs and efforts. When they feel treated humanely, fairly, and equally when evaluating their academic performance and quality, they will try to learn better. Positive evaluative information can be able to induce positive feelings inherent in them (Clore \& Colcomber, 2003). They will construct positive feelings and learning efforts as a longing to improve their academic quality to be better (Marsh \& Martin, 2011; Matovu, 2012; Yusuf, Dramanu, \& Balarabe, 2013) and provide guarantees for active and participative learning classes.

\section{Integrate Thoughts and Behaviors that Motivate}

Thoughts and behaviors that motivate educators are key strategies to train students' academic self-concept. Aware of this, educators have designed various sequences of figures' thoughts packaged in short five-minute, six-minute videos to encourage academic beliefs and efforts in learning. This video played at the beginning and or at the end of meeting, for example: "Confidence is not for yourself, but for everyone who has made you alive and colorful" by Jaye Miler and "Satisfaction lies in the effort, not on results. Striving hard is an essential victory" by Mahatma Gandhi. Beside in visual form, educators also do in audio/verbal oriented to the experiences that educators feel themselves (natural and observe), such as during the college, educator experienced failure in the course of motorics and statistics but still believed and tried to fix it so that educators can finish at the end of college time and experience of doing academic publications (seminar conferences, journals, or textbooks).

Learning behavior is a manifestation of emotional tones series. These emotional tones (e.g. motivation) are "coordinating" with logic to stimulate the motoric movements that we call activity or learning behavior. According to Nalle (male, 21 years old), "The thing that drives the trust and the academic endeavors are exemplary behavior, facilitate my learning, and 
reflect on the expectations of high learning success”. While Lodolaleng (male, 20 years old) added, "educators give appreciation to the results or performance that learners have achieved". Delivering students in effective learning participation is exemplary. Academic self-concept can be trained by transfering inspirational experiences (Wasak \& Blegur, 2017), becoming a model in discipline, learning, and academic production, and appreciating students' learning. This effort gives a higher influence on positive learning behavior (Blegur, Wasak, Tlonaen, \& Manggoa, 2017), students become reluctant to be apathetic and receptive not because of intimidation, but rather because of a growing consciousness to change due to the influence of the thoughts and behaviors learned from educators who are always motivating.

The relationship of mind and behavior to the academic self-concept is not only linear, but also causalistic. Students with good self-concept will also have good motivation (Marsh, Trautwein, Ludtke, Koller, \& Baumert, 2005; Prabadewi \& Widiasavitri, 2014). Motivating thoughts and behaviors refer to one package of speech and action. When educators want to motivate students, they ensure that they speak what they have done and do what they have said (Blegur, Wasak, \& Manu, 2017). When advising students to be diligent in school and having good academic grades, however educators themselves have a record of absences and bad publications are a form of fraud. One package of thought and action makes educators as a respected person. Assertive, disciplined, honest, fair, and productive are supporters of academic beliefs and academic efforts. In addition, avoid comparing the academic quality among fellow students extremely, because it will lead to pulling out themselves (Bong \& Skaalvik, 2003). Train effective academic self-concept is to integrate thoughts and behaviors that motivate implicitly but sustainably, rather than explicitly but insidential.

\section{CONCLUSION}

The dynamics created by educators in classroom learning affect the students directly and indirectly by determining the logic, attitude, and behavior of learning (active-participatory and passive-receptive). Confidence and academic efforts as a unity of academic self-concept of students can be established and trained by educators through the following strategies: 1) Establish logical consequences for students to critically assess their beliefs and efforts while learning, 2) Give challenging responsibilities for students to develop efforts and learning ability totally, 3) Dynamic expression media in encouraging students to think critically and creatively to achieve their goals, 4) Perform solutive-based feedback as a concrete step to train the openness of students on other alternative efforts, 5) Direct, objective, and transparent evaluation of learning outcomes to create a realistic attitude in recognizing the potential of self and the satisfaction of students toward their academic performance, and 6) Integrate motivational thoughts and behaviors to give positive trends to students that everyone has equal opportunities to develop in accordance with the self-potential and to become useful for others.

\section{REFERENCES}

Almasitoh, U. M. (2012). Menciptakan lingkungan yang positif untuk pembelajaran. Magistra, 80(24), 12-25.

Bacon, C. S. (1993). Student responsibility for learning. Adolescence, 28(109), 199-212.

Bell, M. (2010). Supported reflective practice: A programme of peer observation and feedback for academic teaching development. International Journal for Academic Development, 6(1), 29-39. https://doi.org/10.1080/13601440110033643

Blegur, J. (2017). Eksplorasi motivasi belajar peserta didik dengan mediasi metode mengajar. Makalah presentasi pada seminar hasil penelitian pendidikan pemberdayaan hasil

(c) The International Journal of Indian Psychology, ISSN 2348-5396 (e)| ISSN: 2349-3429 (p) | 51 
penelitian melalui seminar: Mendorong peningkatan penulisan artikel dan publikasi (hal. 140-150), 21 Januari, Jakarta, Indonesia.

Blegur, J., Mae, R. M., \& Wasak, M. R. P. (2018). Konsep diri akademik sebagai solusi mengendalikan kecemasan berkomunikasi peserta didik. Indigenous: Jurnal Ilmiah Psikologi, 3(1), 47-59. DOI: https://doi.org/10.23917/indigenous.v3i1.5827

Blegur, J., Wasak, M. R. P., \& Manu, L. (2017). Penilaian formatif peserta didik atas kompetensi pendidik dalam proses pembelajaran. Satya Widya, 33(2), 117-127. DOI 10.24246/j.sw.2017.v33.i2.p117-127

Blegur, J., Wasak, M. R. P., Tlonaen, Z. A., \& Manggoa, M. A. (2017). Students’ behaviour of indiscipline syndrome in teaching and learning process. Educational Administration Research and Review, 1(2), 37-41.

Bong, M., \& Skaalvik, E. M. (2003). Academic self-concept and self-efficacy: How different are they really? Educational Psychology Review, 15(1), 1-40.

Burnett, P. C. (2010). Teacher praise and feedback and students' perceptions of the classroom environment. Educational Psychology: An International Journal of Experimental Education Psychology, 22(1), 5-16. https://doi.org/10.1080/01443410120101215

Byrne, B. M. (1996). Academic self-concept: Its structure, measurement, and relation to academic achievement. In B. A. Bracken (ed), Handbook of self-concept: Developmental, social, and clinical considerations (pp. 287-316). Oxford, England: John Wiley.

Centre for Justice and Crime Prevention. (2012). Positive discipline and classroom management $\left(1^{\text {st }}\right.$ ed). Cape Town, Republic of South Africa: Centre for Justice and Crime Prevention and the Department of Basic Education.

Chen, S. K., Yeh, Y. C., Hwang, F. M., \& Lin, S. S. J. (2013). The relationship between academic self-concept and achievement: A multicohort-multioccasion study. Learning and Individual Differences, 23, 172-278. https://doi.org/10.1016/j.lindif.2012.07.021

Clore, G., \& Colcombe, S. (2003). What is primed by emotion concep and emotion words. In J. Mucsh \& K. C. Klauer (ed), The psychology of evaluation (pp. 335-370). Mahwah, New Jersey: Lawrence Erlbaum Associates, Inc., Publisher.

Creswell, J. W. (2009). Research design: Qualitative, quantitative, and mixed method approaches $\left(3^{\text {rd }}\right.$ ed). Thousand Oaks, California: SAGE Publications.

Efklides, A., \& Petkaki, C. (2005). Effects of mood on students' metacognitive experiences. Learning and Instruction, 415-431. https://doi.org/10.1016/j.learninstruc.2005.07.010

Ghazvini, S. D. (2011). Relationship between academic self-concept and academic performance. Procedia Social and Behavioral Science, 15, 1034-1039. https://doi.org/10.1016/j.sbspro.2011.03.235

Glaser, R. (1984). Education and thinking: The role of knowledge. American Psychologist, 39(2), 93-104. http://dx.doi.org/10.1037/0003-066X.39.2.93

Gulo, W. (2002). Strategi belajar mengajar (cet. 1). Jakarta: Grasindo.

Hassel, H., \& Lourey, J. (2010). The dea(r)th of student responsibility. Journal College Teaching, 53(1), 2-13. https://doi.org/10.3200/CTCH.53.1.2-13

Juliani, R., \& Meliana, F. (2014). Pengaruh strategi genius learning terhadap hasil belajar siswa pada materi fisika topik listrik dinamis kelas ix smp swasta raksana Medan. Jurnal Pendidikan Fisika, 3(1), 34-40. DOI 10.22611/jpf.v3i1.3274

Kaur, G., \& Kumaran, S. J. (2016). Test anxiety and academic self-concept of students. The International Journal of Indian Psychology, 3(4), 90-98. DIP: 18.01.009/20160304

Liu, W. C., \& Wang, C. K. J. (2005). Academic self-concept: A cross-sectional study of grade and gender differences in a Singapore secondary school. Asia Pacific Education Review, 6(1), 20-27. https://doi.org/10.1007/BF03024964 
Marsh, H. W. (1987). The big-fish-little-pond effect on academic self-concept. Journal of Educational Psychology, 79(3), 280-295. http://dx.doi.org/10.1037/00220663.79.3.280

Marsh, H. W., \& Martin, A. J. (2011). Academic self-concept and academic achievement: Relations and causal ordering. British Journal of Educational Psychology, 81(1), 5977. https://doi.org/10.1348/000709910X503501

Marsh, H. W., Trautwein, U., Ludtke, O., Koller, O, \& Baumert, J. (2005). Academic selfconcept, interest, grades, and standardized test scores: Reciprocal effects models of causal ordering. Child Development, 76(2), 379-416. https://doi.org/10.1111/j.14678624.2005.00853.x

Matovu, M. (2012). Academic self-concept and academic achievement among university students. International Online Journal of Educational Science, 4(1), 107-116.

Muijs, R. D. (1997). Predictors of academic achievement and academic self-concept: A longitudinal perspective. British Journal of Educational Psychology, 67(3), 263-277. https://doi.org/10.1111/j.2044-8279.1997.tb01243.x

Musch, J., \& Klauer, K. C. (2003). The psychology of evaluation: An introduction. In J. Mucsh \& K. C. Klauer (ed), The psychology of evaluation (pp. 1-6). Mahwah, New Jersey: Lawrence Erlbaum Associates, Inc., Publisher.

Noriasih, N. K. (2013). Pengaruh model pembelajaran reciprocal teaching terhadap pemahaman bacaan ditinjau dari konsep diri akademik siswa. Jurnal IKA, 11(2), 27-45.

Ordaz-Villegas, G., Acle-Tomasini, G., \& Reyes-Lagunes, L. I. (2014). Development of an academic self concept for adolescents (asca) scale. Journal of Behavioral, Health, \& Social Issues, 5(2), 117-130. https://doi.org/10.5460/jbhsi.v5.2.42304

Pinxten, M., de Fraine, B., van Damme, J., \& D’Haenens, E. (2010). Causal ordering of academic self-concept and achievement: Effects of type of achievement measure. British Journal of Educational Psychology, 80(4), 689-709. https://doi.org/10.1348/000709910X493071

Poulos, A., \& Mahony, M. J. (2008). Effectiveness of feedback: The students' perspective. Assessment \& Evaluation in Higher Education, 33(2), 143-154. https://doi.org/10.1080/02602930601127869

Prabadewi, K. D. L., \& Widiasavitri, P. N. (2014). Hubungan konsep diri akademik dengan motivasi beprestasi pada remaja awal yang tinggal di panti asuhan Denpasar. Jurnal Psikologi Udayana, 1(2), 261-270.

Rossen, J. A. (2010). Academic self-concept. In J. A. Rosen, E. J. Glennie, B. W. Dalton, J. M. Lennon, \& R. N. Bozic (ed), Noncognitive skills in te clasroom: New perspectives on educational research (pp. 117-144). Triangle Park, USA: RTI Press Publication.

Saxon, D. P. (2013). Student responsibility and self-directed learning: An interview with Cristine McPhail. Journal of Developmental Education, 36(3), 14-17.

Simanjuntak, E. T. P., Djahi, I. N., Tamba, K. P., Souisa, J. H., Toisuta, W., Dionisio, A. G., \& Palekahelu, D. T. (2017). Disiplin positif: Pendekatan menyeluruh-manual pelatihan untuk guru (cet. 1). Jakarta: Yayasan Nusantara Sejati.

Snyder, C. R., \& Cowles, C. (1979). Impact of positive and negative feedback based on personality and intellectual assessment. Journal of Consulting and Clinical Psychology, 47(1), 207-209. http://dx.doi.org/10.1037/0022-006X.47.1.207

Strein, W. (1993). Advances in research on academic self-concept: Implications for school psychology. School Psychology Review, 22, 273-284.

Tlonaen, Z. A., \& Blegur, J. (2017). Konsep diri akademik mahasiswa pascasarjana. Scholaria: Jurnal Pendidikan dan Kebudayaan, 7(3), 226-233. DOI 10.24246/j.scholaria.2017.v7.i3.p226-233 
Trickett, E. J., \& Moos, R. H. (1974). Personal correlates of contrasting environments: Student satisfactions in high school classrooms. American Journal of Community Psychology, 2(1), 1-12. https://doi.org/10.1007/BF00894149

Wasak, M. R. P., \& Blegur, J. (2017). Students' indisciplinary behaviour and the alternative solutions in learning process. Paper presented in the $4^{\text {th }}$ international conference on physical education, sport and health (ismina) and workshop (pp. 3-11), April $12^{\text {th }}$, Semarang, Indonesia.

Yusuf, B., Dramanu, \& Balarabe, M. (2013). Relationship between academic self-concept and academic performance of junior high school students in Ghana. European Scientific Journal, 9(34), 93-104.

\section{Acknowledgments}

Researcher team would like to say thank to June A. Jacob, S.Pd., M.A., as the Dean of the Faculty of Teacher Training and Education and Agustinus J. Nafie, S.Pd., M.Or., as the Head of Physical Education, Health, and Recreation Program, which is pleased to grant permission and support for a series of research processes to scientific publications. To the participants who have been willing to prepare the time to be actively involved in the data collection process of the research.

\section{Conflict of Interest}

There is no conflict of interest.

How to cite this article: Blegur. J, Wasak. M. R. P, \& Pabala. P. (2018). Students’ Academic Self-Concept: A Founding Strategy in Learning Process. International Journal of Indian Psychology, 6(4), 44-54. DIP:18.01.046/20180604, DOI:10.25215/0604.046 